\title{
Peter Lowe: information and misinformation about a Scots surgeon of the sixteenth century
}

\author{
IML Donaldson \\ Professor Emeritus, University of Edinburgh and Honorary Librarian, Royal College of Physicians of Edinburgh, Edinburgh, UK
}

\begin{abstract}
The paper reviews what is known of Peter Lowe's surgical education, practice and activities before he obtained the Royal Charter in the last year of the sixteenth century, founding what became the Royal College of Physicians and Surgeons of Glasgow. It attempts to separate probable fact from accumulated fiction then discusses briefly Lowe's possible contributions to the contents of the Charter.
\end{abstract}

KEYWORDS Peter Lowe, Royal College of Physicians and Surgeons of Glasgow

\author{
Correspondence to IML Donaldson \\ Sibbald Library \\ Royal College of Physicians of \\ Edinburgh \\ 9 Queen Street \\ Edinburgh EH2 IJQ, UK
}

e-mail i.m.l.d@ed.ac.uk

DECLARATIONS OF INTERESTS No conflicts of interest declared.

\section{INTRODUCTION}

Compiled by Peter Lowe Scotchman, Arellian, Doctor in the Facultie of Chirurgerie in PARIS, and chirurgian ordinarie to the most victorious and christian King of Fraunce and Nauarre.

Thus does Peter Lowe announce his authorship of The whole course of chirurgerie... published in London in 1597' (which I discussed in a previous article ${ }^{2}$ ). Of the adjectives describing himself, the interpretation of only one Scotchman - has not given rise to argument, contradiction, speculation and a good deal of sheer nonsense since 1889 when Lowe's first, best and most carefully researched biography was published. ${ }^{3}$

In addition to disagreements over the meaning of the adjectives in Lowe's description of himself, a few other controversial matters deserve attention: The title of Maister, which was frequently applied to him, has given rise to questionable assumptions about his education and status and, in recent times, he has been accused of being both a pirate and a spy. Finally, it has been claimed that the later and present state of the Glasgow body which Lowe was instrumental in founding, in which physicians and surgeons were and are equal partners, was brought about by Lowe's supposed vision of the unity of medicine in which physicians and surgeons would form a 'true union'. The bases for this perception of Lowe's intentions at the time of the foundation need to be examined.

Much about Lowe's life remains obscure; the year of his birth is unknown, the details of where, what and how he studied before beginning practice as a surgeon are unclear. Dingwall says that Lowe left Scotland about 1566 and experienced 'the traumas of events such as the St Bartholomew's day massacre, when he is reputed to have been hidden in the king's wardrobe to avoid capture and probable execution'. ${ }^{4}$ No authority is given for the date of 1566 and the surgeon said to have been hidden by King Charles IX during the massacre of St Bartholomew's Eve was Ambroise Paré and not Peter Lowe, as Duncan ${ }^{5}$ (from whom Dingwall quotes) makes clear. Nor was he hidden in a wardrobe. The source of the well-known story about Paré is Brantôme, ${ }^{6}$ who says that during the massacre Paré was told by the king to remain in the king's chambre et garde-robbe, that is, in his bedroom and privy - a much more practicable hiding place than a wardrobe if, indeed, there was such an article of furniture in the sixteenth century.

Lowe's particular religious sectarian affiliations (if any) and his non-medical activities have aroused speculation, some of it more romantic than informed. Even the records of the year of his death disagree among themselves, although, presumably, one must accept the 1610 from his will, which was transcribed and published by Finlayson in $1898,{ }^{7}$ rather than the 1612 of his tomb and the preface to the second edition of the Chirurgerie or the 1617 of a French funerary index. ${ }^{8}$

What is not in doubt is that Peter Lowe was Scots, practised surgery in and around Paris, returned to Scotland, wrote books - two of which, on venereal disease $(1596)^{9}$ and on surgery (four editions: 1597, $1612,1634,1654)$, are extant - settled in Glasgow and was instrumental in obtaining from the Scots King James $\mathrm{VI}$ a Charter to found a medical 'society' in that city which, most unusually for the time, regulated both surgeons and physicians and which continues today as the Royal College of Physicians and Surgeons of Glasgow.

\section{ARELLIAN}

This appellation has attracted various interpretations; that 
it refers to Lowe's place of birth, that it indicates that his medical training took place in Orléan ${ }^{3}$ and even that it might mean that he was a particular admirer of Marcus Aurelius. In 1999, Buchanan and Gately ${ }^{10}$ made the suggestion - apparently in all seriousness - that Lowe may have called himself Arellian out of admiration for the philosophy of Emperor Marcus Aurelius whose books they say that they, also, find personal and moving. Much earlier, Finlayson considered the matter carefully and soberly and cites Aurelianensis applied to Jacques Guillemeau as meaning a native of Orléans. But he was not happy with the analogy since there is no very obvious Scottish place that had a Latin name similar to Arellian and so, somewhat reluctantly it seems, he accepted the firm claim of Dureau, a French doctor (whose letter, from Paris, of 8 March 1877, he quotes in full) that:

Arellian means Orléanais. Peter Lowe was a physician of the Collège d'Orléans (Medicus Aurelianus). I find this [name] in several manuscript registers of 1596 that I have leafed through myself. You should be aware that this former school of medicine received a good number of English physicians. Thus there is no doubt of this fact. ${ }^{3}$ [author's translation]

So Finlayson felt - though reluctantly - that Arellian most probably meant that Lowe was medically trained in Orléans. A few years after Finlayson, Duncan willingly accepted the Orléans story, dismissed the likelihood of Arellian referring to a birthplace and made much of the superior status that he supposed would have attached to a surgeon trained in a medical school. ${ }^{5}$ But neither Finlayson nor Duncan commented on the rather awkward fact that, if Lowe had been a student named in a register at a medical school in 1596, it would be astonishing, to say the least, that he was sufficiently advanced in medicine to be a royal surgeon that same year - in which he also wrote a book on venereal disease - and also to have practised in Paris during the siege of 1590, as he says in his surgical treatise.

Or did Dureau mean that Lowe was already a médecin when he was entered on that register of 1596 in Orléans - in which case, of course, he was not trained in surgery in Orléans. Dureau uses the word médecin; but in the sixteenth century this word had the quite specific meaning of physician - as distinct from surgeon. So was he claiming that Lowe was a physician as well as a surgeon - or, in spite of his being Librarian of the Académie de Médecine - was Dureau simply ignorant of the sixteenthcentury usage and careless in his use of words?

I have searched for information on this 'former school of medicine' in Orléans - unsuccessfully. In the 1950s Goodall also tried to pursue the Orléans story but found that the relevant records had been destroyed in air raids in 1940." There was a Collège de Médecine in Orléans in the eighteenth century, and perhaps this existed in previous centuries, but, at least in the eighteenth century, it was a charitable foundation providing medical care with no suggestion that it educated doctors. There was indeed an ancient and famous Faculté in Orléans, but it was a Faculty of Civil Law (as opposed to Canon Law) and not of medicine. None of the protagonists of Orléans as the explanation of Arellian seems to have been aware that no French university awarded a qualification in surgery in the sixteenth century - not even Paris where surgeons and their apprentices were sometimes considered members of the Faculté de Médecine.

But, with the exception of Finlayson, none of these commentators seems to have been aware that in sixteenth-century France, where Lowe practised for years, it was a very common practice indeed for an author's name in a Latin medical book to be immediately followed by a proper noun indicating his place of birth or the large town nearest to it. Thus we have Jean Fernel and lacobus Sylvius (Jacques Dubois) both Ambiensis from Amiens - Jacques Guillemeau Aurelianensis - from Orléans. A similar practice was followed by the (Latin) Funeral Register of the Parisian Surgeons, ${ }^{8}$ where these adjectives-of-origin are given for almost every surgeon including Ambroise Paré from Laval (Ambrosius Pareus Lavalaeus). But even in this context Arellian is unusual; from its form it seems not to be a Latin (or Latinised) place name and certainly it is not in Graesse, ${ }^{12}$ the standard reference source for Latin and Latinised European names, and nor is anything that could be another form of the word.

Although the practice of using place names in this way was most unusual in English book titles of the period, there is at least one exception. Alexander Dicsone (or Dickson), a Scot who wrote on memory - and of whom we shall hear more later - appears as Alexandri Dicsoni Arelii in the title of his 1583 book on memory. ${ }^{13}$ Not only was this Discone from Errol, a village in Perth and Kinross, or nearby, but, as we shall see, he was an associate of Peter Lowe so it is quite possible that Lowe used an anglicised form of Arelii to describe himself as a native of Errol. In 1682 Christopher Irvin published a little book on Latin nomenclature in Scots history which contains the entry 'Arellius, Earl of Arrol, High Constable of Scotland'. ${ }^{14}$ This information is entirely consistent with Dicsone's use of Arelii. Note, though, that while Dicsone uses a Latin genitive of a presumed place name to describe himself, which would make it clear to anyone familiar with the European style that he was giving the name of his place of origin - even if they had no idea what place this was - Lowe uses what seems to be an English proper adjectival form of the word, thus effectively obscuring its reference to a place of origin.

In 1955 Goodall, in a paper on Lowe, felt that the parallel with Dicsone was probably invalid because he could not 
believe that, in 1596, Lowe would have been willing to admit to any association with the Catholic Earl of Errol who had been involved in a plot to oust James $\mathrm{VI}$ in I589." Goodall promised another explanation of Arellian later in his paper, but this does not appear. He also believed - though on evidence that he himself described as 'far from convincing' - that Lowe was born in Glasgow or the west of Scotland. Scott, on the other hand, concluded that Arellian indicates that Lowe was a native of Errol. ${ }^{15}$

To summarise, one cannot be quite certain that by Arellian Lowe intended to indicate that he was from Errol, though this seems to be the most likely interpretation of such evidence as there is. Perhaps Lowe's familiarity with the common French practice led him to use Arellian in the way he did, assuming, as seems most likely from the evidence we have, that he was, indeed, from Errol. But the appellation is likely to have been as puzzling to his contemporary readers as it has proved to be to modern commentators.

\section{DOCTOR IN THE FACULTIE OF CHIRURGERIE IN PARIS}

Finlayson discussed the use of this title and seems to have concluded that its use was justified; he dismisses the strictures of Astruc' ${ }^{16}$ who says: 'He [Lowe] calls himself a Doctor of the Faculty of Surgery of Paris arrogantly, nay, I say foolishly, since Paris has no Faculty of Surgery, and never created any, but [has] only a Community of Masters of Surgery and that Community creates no Doctors and never created any, only sworn Masters of Surgery as is the case in other cities of Europe'. Finlayson regarded this as simply an attempt to disparage Lowe, of whose book on venereal disease Astruc disapproved. Astruc clearly had a poor opinion of Lowe, but, in fact, most historians would accept that Astruc's objections that Paris never had a 'Faculty of Surgery' and that the Parisian College of Surgeons (Collège de St Côme) did not create Doctors but Masters were quite true for most of the renaissance.

The relations between the Parisian Faculté de Médecine and the surgeons of the Community, later the Collège, of St Côme were complex, tangled and frequently acrimonious and it is often difficult to know how to interpret them. Quesnay adduces evidence that seems to show that, during the reign of Henri III, the 'Maistres chirurgiens' did have the title Doctors - or at least claimed to have it - and were members of a Faculty of Surgeons - and that, in spite of the usual resistance of the Faculté de Médecine, these titles were sometimes tolerated and even perhaps tacitly approved. ${ }^{17}$ Malgaigne, however, dismisses contemptuously the suggestion that the Maistres (Masters) of the Collège ever dreamed of claiming for themselves the title of Doctor. ${ }^{18}$ At this remove and since the records of the Collège de St Côme have now disappeared (see below), it is impossible to know what the true situation was - if, indeed, relations between the communities of the Parisian physicians and of the surgeons were ever stable for long enough in the sixteenth century to be able to speak meaningfully of a single true position. In passing, we should emphasise that, while relations between the Faculté as representative of physicians and the Collège representing the highestqualified surgeons, were often stormy in the sixteenth century, relations between individual physicians and surgeons collaborating in the care of their patients - as they did daily - were almost always respectful and often both warm and truly amicable as the writings of Paré show beyond doubt. ${ }^{18}$ But it is also true, as Finlayson says, that Astruc's was rather an objection against the pretensions of the College of Surgeons than those of Lowe. $^{3}$ That Lowe would have been permitted to describe himself as 'Doctor in the Facultie of Chirurgerie in Paris' in any book printed in France in the late sixteenth century seems improbable.

\section{MAISTER - LOWE'S SURGICAL EDUCATION}

This leads us to consider the title of 'Maister' by which Lowe is described in many contemporary documents and which now almost invariably precedes his name in modern writings. Once again, some modern writers have made unwarranted assumptions about its meaning, often claiming that it implies that Lowe must have held the degree of Master of Arts. Now, Lowe may well have had such a degree - we simply do not know - but the title 'Maister' is not necessarily evidence of it.

Buchanan and Gately state: 'He is referred to as Maister, which is not the Lowland Scots for mister, but a corruption of Le Magister, the French for pedagogue signifying that he had graduated Master of Arts, either at Orléans or Paris.' ${ }^{\prime 0}$ Maister frequently is - and was exactly the 'Lowland Scots' equivalent of mister; Le Magister is not and never was French for pedagogue and Maister did not necessarily signify Master of Arts in the sixteenth century - though it might do so. To suggest that 'Maister' must signify a Master of Arts in sixteenth century Scots is incorrect. The Dictionary of the Scots Language lists 22 senses for the noun Maister as applied to a person. ${ }^{19}$ These include the sense of the modern 'mister' - and, at entry 2I, 'Master of Arts', most commonly in the context of clergyman or schoolmaster.

In sixteenth-century Scots documents Maister may have a number of significations, including, for example, a full member of a trade or professional guild, an employer or master of workmen or servants, simply a polite honorific - as our contemporary 'mister' - or, indeed, a Master of Arts. However, in sixteenth century Paris, Maistre was the correct and official title for a surgeon who had been admitted, by thesis, to the highest academic grade of the College of Surgeons of St Côme - that grade which the 
surgeons are said sometimes, quite possibly illegally, to have called 'Docteur'. It is more than probable that Lowe had been admitted a Maistre of that College - which he then chose to represent as Doctor.

But there is also a further interesting possibility about the nature of Lowe's medical education. There is an entry in the Latin Index Funereus of the College: M. Petrus Louvet, Scotus, Medico-Chirurgus praestantissimus. Obiit 30. Junii anni I6 I 7. Here the M.stands for Magister - Maistre in sixteenth century French (a survival of this type of professional usage in modern French is Maitre as the form of address of an advocate at law) - and Louvet is a perfectly believable version of 'Lowe'; the French alphabet did not contain a letter $W$ at that period and, in France, the terminal 'e' of Lowe might well have been imagined to be pronounced as 'et' (ay). The date of death is wrong - but the dates of demise of other surgeons in the Index do not always correspond to those given in other sources. Goodall points out the error in the date of death and says: "It seems to me likely that "Petrus Louvet, Scotus" was not Peter Lowe." However, he gives no reason other than the error in the date of Lowe's death for his disbelief, and, as we have seen, Lowe's own later books proclaim him to be alive in 1612 when we know from his will that he was already dead in 1610 .

It seems quite possible that it took some years before news of Lowe's death was received in Paris and, perhaps, the year of death recorded was the year in which the news reached Paris. As explained above, it seems almost certain that Louvet was, indeed, Peter Lowe. The Index entry calls Louvet praestantissimus 'outstanding'. There are two other points of interest in this entry: Louvet is the only 'Scotus' in the register and one of only three surgeons described as Medico-Chirurgus - as Finlayson pointed out. ${ }^{3}$ The appellation is puzzling; whether it was intended to distinguish these three from other Maistres, and, if so, in what way, we do not know. It would be extraordinary indeed if Louvet (or Lowe) had been a medicus - that is a physician - as well as a surgeon.

But there is, perhaps, another possibility. According to Quesnay, ${ }^{17}$ in the later sixteenth century there was, apparently, a mechanism by which Parisian Masters of Arts could enter a scheme in which they followed two years' courses in 'elements of medicine' (just what these were we do not know), then were registered as students in surgery in which they attended formal courses at the Collège over four years but were also apprenticed to a Maistre from whom they received practical instruction. Only after this, and with the approval of the Dean, could they present themselves for examination for the Licence in surgery. Further examinations were required to become bachelors and yet more, including a 'thesis', for the grade of Maistre or Docteur.
If all of this is correct - and it would be very difficult to verify now since the records of the Collège had disappeared before $1840^{18}$ - then there may, indeed, have been in the sixteenth century Parisian surgeons who had some training in medicine as well as in surgery, and perhaps Peter Lowe was one of them; if so he must have been a Master of Arts of Paris. In addition to the appellation medico-chirurgus in the Index Funereus, there is one other small indication consistent with Lowe having followed this 'combined' course - though it by no means proves that he did do so.

In the first edition of Lowe's Chirurgerie, part of the text is set out as a series of questions and answers between 'lohn Cointret Deane of the facultie of Chirurgerie in Paris, and Peter Low his Scholler'. John Cointret must be Jean Cointeret and it would seem that Lowe was his apprentice. By chance, information about Cointeret's admission as Maistre in I56I has survived. His thesis was presided over by Estienne de la Rivière and the question was: 'In anthrax should bleeding be pursued until the patient faints?' These theses were just stated and, apparently, not defended by the candidate - that is, they were not examined - so the business was, as Malgaigne says, ${ }^{18}$ somewhat of a parody of the theses of the Faculté de Médecine.

In 1579 Cointeret was surgeon to the Queen-mother and in 1574 he was Chirurgien du Roi et juré du Roi au Châtelet - the appointment that Estienne de la Rivière had held at the time of Cointeret's admission as Maistre. This appointment was one of great importance; the Royal surgeon (or surgeons, sometimes there were two) at the Châtelet were the authorities who examined postulant barber-surgeons and administered the oath that was their licence to practise. They also presided over the examinations for the qualifications of the Surgeons of St Côme where they took precedence over the Provost (sometimes called the Dean) of the Collège. ${ }^{18}$

Lowe says Cointeret was Dean of the 'Faculty' of Surgeons that is, Provost of the Collège de St Côme and perhaps he was - information on names of the holders of the post is very meagre. Quesnay dismisses Cointeret as one of those who wrote nothing and made no advance in surgery ${ }^{17}$ - but this stricture would apply to the majority of medical practitioners in most ages. In the last quarter of the sixteenth century Cointeret was clearly a distinguished and important figure in surgery in Paris. An index of his distinction is that he was one of those called in consultation by the 70 -year-old Ambroise Paré (then principal surgeon to King Henri III), along with Pierre Pigray (a royal surgeon in ordinary), le Fort (one-time Provost or Dean of the College of St Côme) and others in 1580 to advise on a severe injury to one of Parés important noble patients, Christophe des Ursains the Governor of Paris. ${ }^{20}$ According to the Index Funereus, ${ }^{8}$ Cointeret died in 1592 . Since there seem to 
be no records of when Cointeret was Dean (if, indeed, he was) we cannot date Lowe's apprenticeship to him. But it is possible that Lowe's connection with the distinguished Cointeret may have introduced him to court circles and influenced his later appointment as a royal surgeon in ordinary.

If Lowe was one of those who transferred to surgery after a degree of Master of Arts his description of himself as Cointeret's scholar would have represented not just an informal association but indicated that Cointeret was his formal master (Maistre) to whom he was apprenticed to learn practical surgery and to treat patients under supervision during the four years of his registration as a student in surgery. If Lowe had followed this combined course in the theory and practice of surgery at the Collège de St Côme he would have had a much more modern type of training than that of the physicians of the time whose teaching, as they sometimes complained, was purely by study and by disputation with no supervised clinical instruction. Molière's cynical comment in the next century, in an entr'acte in Le Malade Imaginaire, that the newly qualified doctor was licensed 'to drug, to purge, to bleed, to cut and pierce and kill with impunity throughout the land'21 was likely sometimes to have been just. But whether Lowe did follow the 'combined' course of instruction in surgery described by Quesnay and whether the title medicochirurgus in the Index really represents its outcome is uncertain if intriguing.

It seems most likely, therefore, that Lowe trained at the College of Surgeons of St Côme in Paris where he served a surgical apprenticeship under Jean Cointeret and that Maister was perhaps derived from Maistre, the formal title of the most highly qualified French surgeons of the period.

\section{SURGEON TO THE KING OF FRANCE}

Lowe says he was 'chirurgian ordinarie' to the King of France and Navarre - that is to Henri IV. Dureau, quoted by Finlayson, did not find him in the list of 'chirurgiens ordinaires' to the king. Such a list, for 1593, is given by Le Paulmier; ${ }^{22}$ Henri IV had a very large medical entourage at that date, including 15 physicians, five apothecaries and II surgeons. Of the latter, the premier chirurgien, Anthoine Portal, and one other, the Pierre Pigray mentioned above, were in attendance all year, eight more surgeons served by quartier (three months of the year) in pairs and there was one more surgeon 'without quarter'. Lowe does not appear in the list. But the list cannot be taken as applying except to the year 1593 (when Henri finally became master of Paris after reconverting to Catholicism) and we know that there were other royal physicians appointed at other times so other surgeons may also have been appointed later.
In his address to the reader in 1597 Lowe says of his experience: 'For being Chirurgian maior to the Spanish Regiments two yeares at Paris and since that time following the King of Fraunce my Maister in the warrs...' Relevant to this is an entry on Lowe by Matthias in 1761: Petrus Lowe, Glascuensis, Doctor Chirurgiae Parisinus, \& per sex annos primarius Chirurgus Castrensis, apud Gallos, qui de universa arte Chirurgica Anglice scripsit. That is'Peter Lowe of Glasgow, Doctor of Surgery of Paris, and for six years principal(?) surgeon to the armies of the French, who wrote on the whole art of Surgery in English'. ${ }^{23}$ What Matthias's source for this information was we do not know - it could, of course, simply have come from the second edition of Lowe's own book.

Duncan interpreted Chirurgus Castrensis as referring to Lowe's service with the Spanish regiments, ${ }^{5}$ but the text says quite clearly 'for six years principal (?) surgeon to the armies of the French' so it is much more likely that these six years were those spent following Henri IV in his wars. This would correspond to Lowe's remark (if, indeed, it is not simply based on a Latin translation of this very remark) 'next following the French King, my Master, in the warres 6 yeeres' in the second edition of the Chirurgerie published in 1612 . Just what position a chirurgus primarius held is unclear - it might mean 'chief' surgeon but could also mean simply one of the more senior surgeons.

A remark in a letter in State Papers Scotland for 23 May 1595 (of which more below) speaks of a Peter Lowe as 'a new admittit chirurgien to the King of France.' If he was appointed in early I595 or late 1594 this would certainly explain his absence from the household list of 1593. The letter certainly supports Lowe's claim to have been a surgeon to Henri IV, but it seems that he cannot have been active in that position for long if he remained in Scotland or England after 1595, as he appears to have done since his books of 1596 and I597 are dated 'from London' and in 1599 he was petitioning James VI for a Charter.

As a Royal Surgeon in Ordinary he had the duty of attending the French king daily during his period of office - most Ordinary Surgeons served in pairs for three months of the year at a time. When Lowe says in the first edition of his book 'since that time following the King of Fraunce my Maister in the warrs' he was presumably referring to his time as Chirurgus Castrensis rather than what must have been a very brief period of service as 'chirurgian ordinarie' to Henri IV.

\section{PIRACY}

Having discussed Lowe's claims of distinction for himself we may now turn to two other claims of distinction, or notoriety, which have been made on his behalf by more recent commentators. These are of piracy and espionage. Buchanan and Gately say that 'Lowe's piracy and espionage can be 
excused since it was directed against an inimical England, not his homeland.' ${ }^{10}$ Scott, in 1982, made similar claims, although his consideration of their interpretation is more measured..$^{15}$ The evidence for the claims rests on correspondence with the English representative in Scotland in the 1580s and 1590s preserved in the State Papers, Foreign, Scotland. We now have the advantage, not so easily available to earlier authors, that not only the modern transcripts of these papers, but also, and very valuably, images of the original manuscript documents are available online so the accuracy of the transcriptions can be checked.

On 10 March 1588 [I589 new style] William Asheby (Ashby) wrote from Edinburgh to William Cecil, Lord Burghley, Elizabeth of England's Secretary and added a postscript to his letter saying:

There is one Peter Lowe, a Scotchman and a pirate; he hath taken an English ship of Wells in Norfolk laden with corn for Berwick. He came to Montrose and there sold the corn. The master of the ship came to me to procure the King's warrant for the ship and corn. I sent him to Montrose, but for all the King's warrant the poor man could get neither ship nor goods. This pirate is borne out by the Lord Admiral of Scotland, so the town of Montrose dare not deal with him. It were good if a man-of-war were sent by her majesty to these coasts to keep this pirate and his fellow Haggerston in awe, for they will do hurt on the coast of England as they did last year; besides they might intercept messengers coming and going from the King of Spain and prince of Parma.This ship was taken about Coquet Island, and the men set on shore at Bambrough Castle in Northumberland.

The coming of one of her majesty's into these coasts would encourage the King and the protestants and keep the adversaries in fear. ${ }^{24}$

This was swallowed by Scott ${ }^{15}$ as 'evidence' of our Peter Lowe's piracy without any consideration at all of whether the pirate Lowe and Lowe the surgeon were the same man; the name was not an uncommon one. On this Scott then builds a story exonerating Lowe because of 'his attachment to the Marian cause and the anger felt in Scotland over the execution of Mary Stuart in England'. ${ }^{15}$ Significantly, Scott omitted to quote the last line of the postscript which makes it transparent that the King (James VI) and the strongly Protestant Scots government were opposed to both the piracy and the Marian cause. Of course, it is possible that James was privately mourning the execution of his mother, Mary Queen of Scots - certainly he raised a magnificent tomb to her after his accession to the English throne - but he was determined in his pursuit of a public policy that was firmly Protestant and pro-English. Although there were certainly Catholics who would have been angered by Mary's execution, they were a small, though dangerous, minority.
Buchanan and Gately then quote Scott's conclusions adding the error that this (I588 or I589 new style) was the year of Mary's execution (she was executed in February I587). ${ }^{10}$ We are relieved of the necessity of seeking evidence for the identity of the pirate Lowe and the surgeon Lowe by an examination of the original manuscript letter which makes it practically certain that the name of the pirate was Peter Love and not Peter Lowe; Geyer-Kordesch and Macdonald came to the same conclusion in 1999..$^{25}$ But Scott also claims that Lowe was in Scotland in December 1588 because a Peter Lowe witnessed a deed of land transfer between Peter Hay of Megginch and 'the brother of Lord Hay'; he and another witness are described as 'servioribus dicti Pet.' - servants of the said Peter. Once again, the critical question is whether this Peter Lowe and the surgeon were the same person. They may have been, but no evidence has been adduced that they were. In summary, there is no evidence that our Peter Lowe was a pirate, whether or not he was in Scotland in late 1588.

\section{ESPIONAGE}

The entire evidence that the surgeon Peter Lowe may have been engaged in spying of some kind also depends on a footnote, this time in a letter written on 23 May 1595 from a Dr Macartney to Robert Bowes, Elizabeth's representative in Edinburgh, who sent it on to Westminster. The transcript reads:

There is a new admittit chirurgien to the King of France, called Mr. Lowe, Scottishman, who was servant to Dickson when he was in England. This man has 'blokkit' [planned] the matter of the casket and brought it to perfection. ${ }^{26}$

This time it seems reasonable to suppose that Mr Lowe was, indeed, Peter Lowe the surgeon and the whole question of Lowe's possible espionage depends on interpretation of what the 'matter of the casket' was and what 'brought it to perfection' means. If there is a key to the question it must lie in the activities of Alexander Dickson, or Dicsone as he was usually called at the time. About Dicsone's life more is known than about Lowe's - see particularly the articles by Peter Beal. ${ }^{27,28}$ Dicsone was a friend of Giordano Bruno and, like Bruno, he wrote about a technique for improving memory. In 1583 and 1584 Dicsone was associated with the Earl of Leicester and Sir Philip Sidney and was thus close to Elizabeth's court. Perhaps significantly, Sidney was son-inlaw to Sir Frances Walsingham, Elizabeth's master of counter-espionage.

But by 1588 Dicsone was in the service of the Catholic rebel the Earl of Hay. He was censured and warned by King James VI of Scotland (Figure I) for conveying Catholic correspondence. However, the king was indulgent to him in spite of this and his association with 


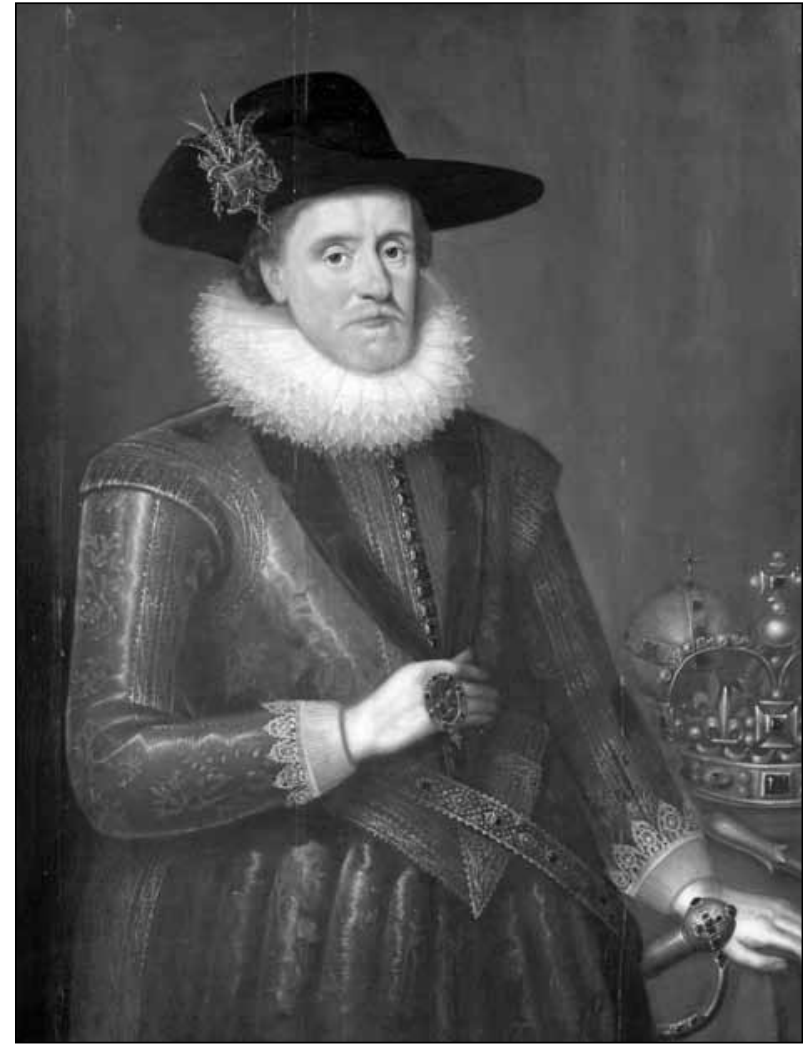

FIGURE I Contemporary portrait of King James VI of Scotland by an unknown artist (with kind permission of the Royal College of Physicians and Surgeons of Glasgow.)

Hay continued. This raises the suspicion that he was not simply regarded (at least in Scotland) as a Catholic agent. It seems that he offered allegiance both to the Scottish Catholic nobility and to James VI. Dicsone was apparently sent on a number of missions to England, France and the Low Countries, but by 1586 was distrusted by both the English and French agents. In 1598 he was reported to Sir Robert Cecil in England as 'an enemy of your state'. But King James apparently found him useful and continued to employ him as a propagandist.

Our only definite evidence of Lowe's association with Dicsone is the remark in the letter of 1595 quoted above. Dicsone admitted in 1595 in a letter to William Cecil, Lord Burghley, that he had given his friend d'Aubespine a 'casket' holding letters containing military information that might have been useful to English enemies. But whether this was recently or a decade earlier is unclear. Guillaume de l'Aubespine (1547-1629), Baron de Châteauneuf, was appointed French ambassador in England in 1585 - to Walsingham's displeasure since he was believed to be much more sympathetic to the imprisoned Mary Queen of Scots than had been his predecessor. From Dicsone's letter it seems more likely that the gift had been in the 1580s when Dicsone and d'Aubespine were both in England. In any event, in 1595 Dicsone was offering the English Council to retrieve the casket from d'Aubespine in Paris - he had ceased to be French Ambassador to
England after 1589 - though denying it contained any papers detrimental to English interests.

The letter of May 1595 to Bowes in Edinburgh associates Lowe with the affair of the casket - though, again, we do not know if his association was in 1595 or a decade earlier. Just what was Lowe's part in all this is even more obscure. The letter says: 'This man has 'blokkit' [planned] the matter of the casket and brought it to perfection'; if we accept that blokkit here means planned rather than the opposite 'blocked' - which it could also mean at this date - was the plan that of delivering the casket to d'Ausbespine, which had already taken place, or of recovering it from him as Dicsone was now offering to do? Indeed it seems that Dicsone did try to recover the casket, though whether he was successful is unclear.And we do not know just when Lowe was 'servant to Dicsone when he was in England' - recently in 1595 or a decade earlier when we know Dicsone was in England but have no evidence that Lowe was.

On the interpretation of all this turns whether Lowe was likely to have been a Catholic agent in the 1580s when Mary was plotting against Elizabeth or an agent for the English - and perhaps the Scots - in 1595, eight years after Mary's execution. Scott assumed that Lowe was a Catholic agent on the grounds that Errol was a centre of Marian sympathy and Dicsone was a Catholic agent and was Lowe's friend $;^{15}$ this may be true, but it is building a great deal on the supposed friendship of Dicsone and Lowe. Certainly Lowe's use of the appellation Arellian suggests - as we have said - that he was following the very eccentric use of the word by Dicsone in the title of his book on memory and so perhaps supports an association between them closer than servant and master - though, again, the title of servant in the sixteenth century might not necessarily imply a very inferior status.

Lowe was in London before the end of the sixteenth century and he dedicated his first book from there in 1596 to Elizabeth's then favourite, the Earl of Essex. Elizabeth was still queen and William Cecil, Lord Burghley, was still alive and influential. Macartney's letter to Bowes of May I595 mentioning Dicsone and Lowe was sent to Whitehall and would have been seen by Burghley's son Robert Cecil who had been Secretary of State since Walsingham's death in 1590. Unless Lowe was very foolhardy indeed, it is rather difficult to believe that he can have been acting against English interests. However, the information we have is simply inadequate for us to know when, for whom and in what capacity Lowe may have been an agent of espionage, if indeed, he was, and it seems unlikely that it will be possible to find out now.

\section{'RELIGION'}

Comrie, writing of Lowe's continental sojourn, says:'The 
period included such memorable historical events as the Massacre of St. Bartholomew and the Revolt of the Netherlands. From the side on which Lowe was serving, it appears that he was then a Catholic; and as he was later "ordinary Chyrurgion to the French King and Navarre, [sic]" he must have changed sides about 1590 , and probably at the same time changed his religion. ${ }^{29}$ Scott ${ }^{15}$ and Buchanan and Gately ${ }^{10}$ speculate at length about Lowe's religious affiliation and how it might have changed over his life according to whom he was serving; but, in France at least, it is quite unsafe to assume that a medical attendant must have shared his master's religious persuasion - there are several instances in which we know that this was definitely not the case. We simply do not have any information about Lowe's religious sentiments and speculation about them is idle.

\section{LOWE AND THE GLASGOW CHARTER}

Several authors speak of Lowe's founding 'The Faculty of Physicians and Surgeons of Glasgow'; the more recent writers point out that this body is now the Royal College of Physicians and Surgeons of Glasgow. All refer to the Royal Charter of 1599 as the instrument of this foundation and all attribute its acquisition to Lowe. Neither the importance of the Charter nor Lowe's agency in obtaining it is controversial. However, one cannot say the same about some authors' description of just what it was that came into existence in the last year of the sixteenth century.

Let us consider two ends of the spectrum of opinion. First we have Comrie in 1932 who is circumspect and accurate in describing the foundation as a regulatory body, though less so in speaking of the neonate as already 'the Faculty': 'The great work of Peter Lowe was the establishment of the Faculty of Physicians and Surgeons, which embraced within its powers the regulation of the practice of medicine, surgery and pharmacy in the west of Scotland, The charter instituted medico-legal examiners who reported to the authorities.'29 At the other extreme, Guthrie, writing in 1965, is scrupulous in speaking of 'what came to be known as the Faculty'. ${ }^{30}$ Here is his account of what Lowe brought into being in 1599 and his reasons for so doing:

Three and a half centuries ago Peter Lowe, with a brilliant stroke of genius and a vision far ahead of his time, resolved to put an end to the age-long separation between Medicine and Surgery by founding what came to be known as The Faculty of Physicians and Surgeons of Glasgow. Only now, in the second half of the 20th century are we beginning to appreciate the wisdom and foresight displayed by Peter Lowe when he founded this College in 1599 with the assistance of Robert Hamilton, Physician and William Spang, Apothecary... ${ }^{30}$
His paper ends: 'Three hundred and fifty years ago, Peter Lowe founded this Royal College, re-uniting physicians and surgeons after centuries of separation. ${ }^{30}$ Is this remarkable piece of hagiography based on any evidence? Guthrie believed that medicine and surgery ought not to be separated and that physicians and surgeons should collaborate and not compete; was this also Lowe's belief? Did he express this belief by seeking a Royal Charter for the purpose of bringing into being a 'professional society' in which physicians and surgeons would be equals and not rivals? As far as I know none of his contemporaries credits Lowe with such beliefs so we can seek evidence only in his own account of his reasons for petitioning James VI and in the Charter itself. Of course, if documents containing the actual text of Lowe's petition or records of discussion of it with the King and Council were extant, these would be very valuable.

In the second edition of his book on surgery, published posthumously though purporting to be from his house in Glasgow of 20 December 1612, Lowe gives his reasons for seeking the charter; he was concerned by the activities of 'certaine abusers of our Art, of diuers sorts and ranks of people, whereof we haue good store... who ordinarily doe passe without either tryall or punishment'. By petitioning the King and Council he says: 'I got a priuiledge vnder his highnes priuie seale, to try and examine all men vpon the Art of Chirurgerie, to discharge, \& allow in the West parts of Scotland, who were worthy, or vnworthy, to professe the same.' Finlayson quotes the whole of the relevant text. ${ }^{3}$

The purpose is simple - to suppress the practice of incompetent surgeons. There is not a word about the unity of medicine or the amity there should be between physicians - who are not mentioned at all - and surgeons. If such considerations motivated Lowe he did not mention them. Geyer-Kordesch and Macdonald speak of the petition of Lowe and Hamilton, ${ }^{25}$ but Lowe does not mention Hamilton at all; he may have been associated with the petition, but, again, we have no evidence that he was.

The 'Charter' is, in fact, a letter under the Privy Seal. It is too long to quote here in full; again, the full text is in Finlayson. ${ }^{3}$ The salient points are: the Charter directs 'Maister Peter Low, ... with the assistance of Mr. Robert Hamiltone, professoure [this just means practitioner] of medicine, and their successouris, indwelleris of our Citie of Glasgow' to summon and examine all surgical practitioners in several specified regions of the west of Scotland on their knowledge of the theory and practice of surgery and if, satisfied, to license them to practise, but only within the limits of their capacity.

Penalties are specified for disobedience, including, interestingly, the provision that half of all fines on 
conviction are to go to the convicting magistrates and half to be at the disposal of the 'visitors' - that is Lowe and Hamilton or their successors. Then there is a requirement for the 'visitors' to make forensic reports to the magistrates on suspected murder victims or others hurt, poisoned, or dying suddenly and to set up rules for the practice of surgery and punish those who disobey them. The practice of medicine is to be more lightly regulated: no one is to practise without a 'testimonial' from a famous university where medicine is taught (Scotland had no such university at the time) or with the permission of the 'chief mediciner' to the king or queen. Notably there is no provision to examine those who wish to practise medicine - only to examine their papers.

The sale of drugs and poisons is to be controlled by the authority of one William Spang, apothecary. Finally, the visitors 'with their brethren and successors' are to give free advice to 'poor diseased people' on the first Monday of each month. The Charter ends by setting out the exemptions and privileges to be enjoyed by the visitors and their successors.

Interestingly there are no provisions for any of those examined in surgery or permitted to practise medicine to be admitted to the society, although the mention of successors presumably implies that the visitors might add to their brethren as they wished - as, indeed, they did.

The Charter itself is more wide-ranging than Lowe's petition (at least as he reports it) and one must wonder whether this wider range might have been imposed by the opinions of the King and Council. It has been argued that Lowe influenced these decisions; perhaps he did discuss the matter with the King and Council and persuaded them to a view he himself held, but we have no evidence at all of his having done so.

A search of the Register of the Privy Council of Scotland ${ }^{31}$ for the relevant period sadly yields no evidence that copies of either the petition or any Privy Council discussion of it have been preserved. The Register of the Privy Seal of Scotland after I584 does not seem to have been published yet; in any case, this register records only the text of the Letters under the Seal, and we already have the text of Lowe's Letter - that is, the Charter.

For its date the Charter is an impressive instrument indeed for the regulation of surgery and the sale of poisons and drugs and, to a lesser extent, the licensing of physicians in the west of Scotland. But that is all it is. It does not found a College or a Faculty - that title was assumed later by the brethren - it says nothing of teaching or apprenticeship nor of the 'unity of medicine' or the relations between physicians and surgeons.
The development of the foundation into a Faculty and finally a Royal College of both physicians and surgeons was surely the result of the activity, attitudes and beliefs of its brethren over years and centuries. It is very hard to avoid the conclusion that Guthrie's claims in his encomium of Lowe about his vision and prescience were generated by Guthrie's own beliefs and not by any expressed opinions of Lowe on the philosophy of how medicine should be practised, on the unity of medicine and the amity or otherwise of physicians and surgeons. Nor do the provisions of the original Charter which Lowe obtained express any such ideas.

However, it is, perhaps, possible - particularly if Lowe had followed a 'combined' course in medicine and surgery in Paris - that he might have felt that regulating both surgery and medicine through a single body was desirable and might have influenced the King and Council to that end. If the original petition or some record of its discussion in Council had been preserved this might have thrown light on Lowe's opinions at the time. But, so far, no such documents have come to light.

\section{CONCLUSION}

Lowe, then, remains an enigmatic figure. His greatest medical achievement was surely his obtaining in 1599 the Royal Charter that led to the foundation of what became the Faculty - now the Royal College - of Physicians and Surgeons of Glasgow. It is sad that the loss of the records of the venerable surgical Collège de St Côme in Paris, the earliest professional body of surgeons, means that it is not now possible to verify Quesnay's claims about the existence of what one might call a combined training in medicine and surgery in the later sixteenth century. If such a course of training existed and if Lowe was one of those Parisian Masters of Arts who transferred to surgery via a course in medicine, perhaps this influenced him in founding a Scottish society which, at its foundation, regulated both surgery and medicine and later developed into a society in which the relations between surgeons and physicians were as associates rather than as rivals.

Finlayson, in his excellent biography of Lowe, has probably recounted all that can usefully be said about Lowe's later years in Glasgow. An obvious question remains about why Lowe decided to settle in Glasgow - quite a small town at the time - and found a medical association there when there was already a wellestablished surgical professional body in Edinburgh. Is it possible that it was the very existence of the exclusively surgical Incorporation of Surgeons and Barbers in Edinburgh that led Lowe to go to Glasgow to found there a medical professional society with a broader membership and with the duty of overseeing the practice of both physicians and surgeons? As with so much about Lowe's life we shall probably never know. 
Acknowledgement Pointers to many of the primary sources used in this article come from Finlayson's and Duncan's books of the late nineteenth century, ${ }^{3,5}$ Goodall's paper in 1955" and Scott's article of 1982. ${ }^{15}$ Although my interpretations of the sources often differ from theirs, without their work the information about Lowe would have been much more difficult to find.

\section{REFERENCES}

I Lowe P. THE WHOLE COVRSE OF chirurgerie, wherein is briefly set downe the causes, signes, prognostications \& curations of all sorts of tumors, wounds, vlcers, fractures, dislocations \& all other diseases, vsually practised by chirurgions, according to the opinion of all our auncient doctours in chirurgerie. London: Printed by Thomas Purfoot; 1597.

2 Donaldson IML. Peter Lowe's Whole Course of Chirurgerie... 1597.J R Coll Physicians Edinb 2013; 43:374-6.

3 Finlayson J. Account of the life and works of Maister Peter Lowe: the founder of the Faculty of Physicians and Surgeons of Glasgow. Glasgow: James Maclehose \& Sons; 1889.

4 Dingwall HM. Lowe, Peter (c.1550-1610). In: Lawrence Goldman (ed.) Oxford Dictionary of National Biography. Oxford: Oxford University Press. Online ed.,http://www.oxforddnb.com/view/ article/I 7086.

5 Duncan A. Memorials of the Faculty of Physicians and Surgeons of Glasgow 1599-1850. Glasgow: James Maclehose and Sons; 1896. p.2I-38

6 Brantôme P. Oeuvres complètes de Pierre de Bourdeille Seigneur de Brantôme ... par Ludovic Lalanne. Vol. 5. Paris: Jules Renouard; 1869. p.256

7 Finlayson J. The last will and testament, with the inventory of the estate, of Maister Peter Lowe, founder of the Faculty of Physicians and Surgeons, Glasgow. Glasgow:Alex MacDougall; 1898.

8 Devaux J. Index funereus chirurgorum Parisiensium, ab anno I3/5 ad annum I7/4, opera M.J. D.V. Paris: apud S Ganeau; I7|4.

9 Lowe P. Easie, certaine, and perfect method to cure the Spanish sickness... London: James Roberts; 1596.

10 Buchanan WW, Gately JF. Maister Peter Lowe (circa 1550-1610): founder of the Royal College of Physicians and Surgeons of Glasgow. Proc R Coll Physicians Edinb 1999; 29:338-48.

II Goodall AL. The Royal Faculty of Physicians and Surgeons. J Hist Med Allied Sci 1955; X:207-25.

12 Graesse JG. Orbis latinus oder Verzeichnis der wichtigsten lateinischen Orts- und Ländernamen: ein Supplement zu jedem lateinischen und geographischen Wörterbuch. Benedict F, editor. Berlin: Richard Carl Schmidt \& Co.; 1909

I3 Dicsone A. Alexandri Dicsoni arelii de vmbra rationis \& iudicij: siue de memoriæ virtute Prosopopoeia. Ad illustrisimum DD Robertum Dudlæum Comitem Licestaræum, \&c. London: Excudebat Thomas Vautrollerius Typographus; 1583.

14 Irvin C. Historiae Scotiae nomenclatura Latino-vernacula:... Edinburgh: Gideon Schaw; 1682. p. I8.

I5 Scott L. A note on the life of Peter Lowe, Scotchman, Arellian, Doctor in the Facultie of Chirurgerie in Paris, and Chirurgion Ordinarie to the Most Victorious and Christian King of Fraunce and Navarre. Birmingham, Alabama: Classics of Medicine Library; 1982.
16 Astruc J. De morbis venereis libri novem... Vol. II. Paris: Guillaume Cavellier; 1740.

17 Quesnay F. Recherches critiques et historiques sur l'origine, sur les divers états et sur les progrès de la chirurgie en France. Paris: Charles Osmont; 1744.

I8 Malgaigne J-F. Oeuvres complètes d'Ambroise Paré / revues et collationnées sur toutes les éditions, avec les variantes ... et precédées d'une introduction sur l'origine et les progrès de la chirurgie en Occident ... et sur la vie et les ouvrages d'Ambroise Paré, par J.-F. Malgaigne. Vol. I. Paris: Baillière; 1840.

19 Dictionary of the Scots Language. http://www.dsl.ac.uk

20 Paré A. Discours d'Ambroise Paré, Conseiller et Premier Chirurgien du Roy. Ascavoir, De La Mumie, De La Licorne, Des Venins, et De La Peste. Paris: Chez Gabriel Buon; 1582

21 Molière. Le Malade Imaginaire; 1673.

22 Le Paulmier C-S. Ambroise Paré d'après de nouveaux documents découverts aux Archives Nationales et des papiers de famille/par le docteur Le Paulmier. Paris: Charavay Frères; 1884.

23 Matthias G. Conspectus historiae medicorum chronologicus. Göttingen: Apud Viduam Vandenhoeck; I76I. p.378.

24 Boyd WK, editor. Calendar of State Papers relating to Scotland and Mary, Queen of Scots, 1547-1603. Vol. 9 (1586-8). Edinburgh: HM General Register House; I588-9. p.709.

25 Geyer-Kordesch J, Macdonald F. The history of the Royal College of Physicians and Surgeons of Glasgow 1599- / 858. London: Hambledon Press; 1999. pp.43-4.

26 Boyd WK, editor. Calendar of State Papers relating to Scotland and Mary, Queen of Scots, 1547-I 603.Vol. I I (1593-5). Reign: Elizabeth I. Entry number: 548. p.598. Document ref:SP 52/55 f.II3.

27 Beal P. Dicsone, Alexander (bap. 1558, d. 1603/4). In: H. C. G. Matthew and Brian Harrison (eds.) Oxford Dictionary of National Biography. Oxford: Oxford University Press; 2004. Online ed., edited by Lawrence Goldman, January 2008. http://www. oxforddnb.com/view/article/73792.

28 Beal P. Alexander Dicsone, Elizabethan philosopher, propagandist, spy: a checklist of his writings. The Library 200I; 2:120-30. doi:I0.1093/library/2.2.120. See also 394 [addenda].

29 Comrie JD. History of Scottish medicine. 2nd ed. Vol. I London: Balliere Tindall \& Cox for the Wellcome Historical Medical Museum; 1932. p.350

30 Guthrie D. The achievement of Peter Lowe, and the unity of physician and surgeon. Scott Med J 1965; 10:26I-8.

31 Masson D, editor. The Register of the Privy Council of Scotland. Vols.V-VI. Edinburgh: General Register House; I882, 1884. 